\title{
Effects on Soybean Growth and Yield of Wheat-Soybean Intercropping System
}

\author{
Fernando Ross ${ }^{1}$ and Pablo E. Abbate ${ }^{2}$ \\ 1Estación Experimental Integrada Barrow, Instituto Nacional de Tecnología agropecuaria (INTA). Tres Arroyos, \\ Buenos Aires, Argentina. CC 50 (7500). \\ ${ }^{2}$ Unidad Integrada, Estación Experimental Agropecuaria Balcarce, INTA and Facultad de Ciencias Agrarias of \\ Univ. Nacional de Mar del Plata. Balcarce, Buenos Aires, Argentina. CC 275 (7620). \\ ross.fernando@inta.gob.ar
}

\begin{abstract}
It has been demonstrated that soybean (Glycine max) produces lower yields at relay intercropping with wheat (Triticum aestivum) than if it is sown as a sole crop. However, most studies considered wider or irregular soybean row spacing, compromising its capacity to recover after wheat harvest. This work studied the stress effects in relay soybean intercropping and suggests narrowing row spacing to improve soybean performance. The aims were (i) to compare growth and yield of two planting patterns and (ii) to separate the effect of water stress (WS) from the effects of other stress factors (OSF) induced by wheat on intercropping soybean. WS was evaluated comparing above-ground dry and grain yield of irrigated and non irrigated intercropping soybean, and OSF was evaluated comparing intercropping soybean with another treatment in which wheat straw (aerial biomass) was eliminated at soybean emergence, both irrigated treatments. In wheat, similar yields were obtained in treatments with an intercropping planting pattern with two rows for wheat and one for soybean (2:1) compared to three rows for wheat and one row for soybean (3:1). However, intercropping soybean at narrow row spacing $(52 \mathrm{~cm}$; 2:1) improve yielded $23 \%$ more than intercropping at $70 \mathrm{~cm}$ (3:1). During wheat-soybean coexistence, OSF prevailed on soybean and this effect persisted in later stages. After wheat harvest, OSF reduced the amount of light interception from R1 to R5 and depressed the crop growth rate (CGR) in 34\%. However, in this period, WS also affected the radiation use efficiencies (RUE) which explained the greater fraction (66\%) of the total stress induced by wheat in soybean CGR. Intercrop soybean yielded $182 \mathrm{~g} \mathrm{~m}^{-2}$ less compared to the unstressed sole crop control. Considering the wheat effects on soybean growth, $63 \%(116.5 \mathrm{~g} \mathrm{~m}-2)$ of the total yield lost were due to WS. Therefore, most of the performance of relay intercropping soybean was linked with water disponibility since early stages. However, at optimum water condition wheat competition by light and resources also affected soybean yield (OSF: $37 \%)$.
\end{abstract}

Keywords: Intercropping, stress, growth, yield.

\section{Introduction}

Wheat-soybean double cropping is well established in Argentine pampas north to $34^{\circ} \mathrm{S}$ (Calviño et al., 2003). However, in the region there is a substantial scope between $34^{\circ} \mathrm{S}$ and $39^{\circ} \mathrm{S}$ in which soybean as second crop after wheat is frequently unprofitable (Calviño et al., 2003). Like many other similar regions in the world, latesown soybean grain yield is severely restricted by a shorter crop cycle and by an important drop in temperature, radiation and photoperiod during the reproductive stages. In the southern Argentine pampas, these conditions lead to drastic reductions in seed number and seed mass; a reduction of $56 \mathrm{~kg} \mathrm{ha}^{-1}$ per day in yield was reported at a delayed planting date of soybean in double cropping after wheat, highlighting the importance of advancing the sowing date (Calviño et al., 2003). Monzon et al. (2007), by means of simulation, estimated that the increase in temperature in the last three decades at Balcarce (a location in the south Argentine pampas), accelerated the development of wheat advanced wheat harvest and this could have allowed earlier sowing of double cropped soybean, increased soybean yield at a rate of $26.2 \mathrm{~kg} \mathrm{ha}^{-1}$ year ${ }^{-1}$.

In several environments, relay intercropping (i.e. the sowing of soybean into wheat during grain filling) has been proposed as an alternative of sequential double cropping (i.e. the sowing of soybean immediately after the 
wheat harvest) to early soybean sowing date (Jeffers and Triplett, 1979; Chan et al., 1980; Reinbott et al., 1987; Porter and Khalilian, 1995; Wallace et al., 1996; Duncan and Schapaugh, 1997; Caviglia, 2005). In general, intercropped soybean produced lower yields compared to the control sole-crop at same sowing date (Jeffers and Triplett Jr, 1979; Chan et al., 1980; Reinbott et al., 1987; Duncan and Schapaugh, 1997; Caviglia et al., 2004; Caviglia, 2005), showing that relay-intercropping soybean was limited by wheat competition.

With a wider row spacing $(70 \mathrm{~cm})$, relay-intercropping soybean intercepted less light than their control solecrops and then soybeans in double cropping (Caviglia, 2005). However, light interception could improve if soybean row spacing was reduced, and this would probably, determine a better crop growth rate at the critical reproductive stages of yield determination (Shibles and Weber, 1966; Andrade et al., 2002). Nevertheless, in intercropping systems, planting patterns with narrow soybean row spacing imply lower number of wheat rows per unit area and could depress its performance.

Planting patterns have shown diverse results or unclear effects on wheat yield. Previous reports have shown less wheat yield at wide row spacing (Jeffers and Triplett, 1979; Chan et al., 1980; Tompkins et al., 1991; Wallace et al., 1996; Lázaro and Abbate, 1997; Senigagliesi, 1998). However, in other similar studies, no yield effect was observed on wheat due to wider row spacing (Fischer, 1976; Porter and Khalilian, 1995; Caviglia, 2005).

Few studies have evaluated survival, growth and development of intercropped soybean under different water regimes. Under reduced water deficit, soybean yielded satisfactorily at field experiments (Wallace et al., 1992); however, in higher water deficits, soybean plants did not survive the emergence stage (Chan et al., 1980). Water deficit at soybean implantation can reduce the plant stand and could result in lower crop growth rate at vegetative and/or reproductive stages, finally depressing grain yield. In order to understand how a preceding wheat crop causes lower soybean yields, in the present study, the effect of water stress is separated from the effects of deficiencies of other resources (not water), especially light. The hypotheses set forth are: (i) in relayintercropping systems under wider row spacing and rainfed conditions, soybean yield increases with lower row spacing and (ii) water stress fully explains yield reductions in soybean intercropping.

\section{Materials and methods}

Experiments were conducted at Unidad Integrada Balcarce, Argentina ( $\left.37^{\circ} 45^{\prime} \mathrm{S}, 58^{\circ} 18^{\prime} \mathrm{O}, 130 \mathrm{~m}\right)$ during the 2003/04 and 2004/05 growing seasons. The soil was loamy, illitic, thermic, typic Argiudol (USDA Taxonomy) rich in organic matter (5.5\%), without physical limitations and moderately deficient in phosphorus. To minimize nutrient deficiency, the soil was fertilized with sufficient amount of phosphorus and nitrogen before wheat sowing ( $3 \mathrm{~g} \mathrm{~m}^{-2}$ of $\mathrm{P}$ and $17 \mathrm{~g} \mathrm{~m}^{-2}$ of $\mathrm{N}$ on each year). Pests and diseases were adequately controlled. Wheat

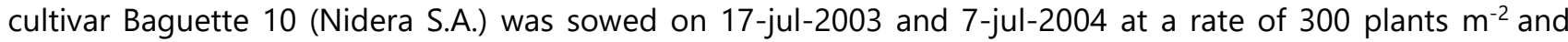
soybean cultivar A3901 (Asgrow S.A.) was sowed at the first half of the wheat grain filling stage (29-nov-2003 and 2-dic-2004, respectively) at a rate of 30 plants $\mathrm{m}^{-2}$. Subsequently, soybean irrigation treatments were applied using drip irrigation system, one hose per soybean row, and estimating water demand by water balance (Allen et al., 1998). Treatments were seeded in plots of $3.15 \mathrm{~m}$ breadth (18-row, seeder with $17.5 \mathrm{~cm}$ rows spacing) and 9 m length.

Treatments were as follows wheat-soybean sequence:

T1: two rows of wheat planted and one not planted, with soybeans planted at a row spacing of $52 \mathrm{~cm}$ spacing without irrigation (Fig. 1a, 2:1);

T2: three rows of wheat planted and one not planted, with soybeans planted at a row spacing of $70 \mathrm{~cm}$ spacing without irrigation (Fig. 1b, 3:1);

T3: wheat control with all rows planted without irrigation (Fig. 1c, 1:0);

T4: similar to T1 but with irrigation; 
T5: similar to T4 but all straw of wheat was eliminated to ground level at soybean emergence.

Soybean water stress was evaluated comparing growth and yield of irrigated T4 and non-irrigated T1, both 2:1 (Fig. 1a). Other stresses induced by wheat (mainly due to radiation competition) were grouped into Others Stress Factors (OSF) and were evaluated comparing intercropping soybean T4 with T5. In this case, both treatments were irrigated to avoid water stress effects and their interactions.

\section{Statistical Analysis}

The experimental design of each experiment was randomized complete blocks with four and three repetitions, in the first and second year, respectively. The data from both experiments was subjected to variance analysis (ANOVA). The level of significance used was $P<0.05$. The analysis was based on the following main contrasts:

1- The effect of planting pattern on wheat productivity was evaluated by comparing treatments $\mathrm{T} 1, \mathrm{~T} 2$ and $\mathrm{T} 3$.

2- The effect of row spacing on soybean productivity was evaluated comparing treatments $\mathrm{T} 1 \mathrm{and} \mathrm{T} 2$.

3- Water stress on soybean was evaluated comparing T4 and T1.

4- Others stress factors on soybean was evaluated comparing T5 and T4.

Stress by deficiency is the abnormal crop functioning by lack of resources that affects the growth and/or development. Then, one form of evaluating the stress or deficiency is through the effect on crop growth. The level of stress on relay intercropping soybean was determined in a similar way as in Greenwood for $\mathrm{N}$ stress (Greenwood, 1976), focusing on separating water stress from stress by other factors:

$$
\mathrm{TS}=W S+O S F=100[1] \quad \mathrm{WS}=\frac{T 4-T 1}{T 5-T 1} * 100[2] \quad \mathrm{OSF}=\frac{T 5-T 4}{T 5-T 1} * 100[3]
$$

where TS is the effect of all deficiencies that induce stress and depress soybeans performance, WS is the effect of water stress and OSF is the effect of deficiencies other than water prompted by wheat that affects the soybean growth and/or development. With deficiencies having been defined this way, the sum of partial stresses (WS and OSF) is equal to all intercropping stresses (TS). This methodology assumes that the effects by OSF will be increased if the water deficit reduces. Furthermore, this is the natural order of removal of limitations; i.e. when rain or irrigation removes the water stress then other factors of stress prevail.

Linear regression analyses were used which all replication data for comparison of relationships between variables (Draper and Smith, 1966). In some cases, to delete the Year effects, regressions were considered with residuals of means for each year. When nonlinear equations were fit, an interactive method for adjusting variables was used, without variable changes (Broyden, 1965).

\section{Wheat measurements}

The stages of development of wheat were measured according to Zadoks et al. (1974). Dates of anthesis, defined as the moment in which $50 \%$ of the spikes exposed at least one another, were determined by linear interpolation from measurements on 30 spikes per plot every 3 days. Additionally, the beginning of the period of growth of the spikes (BSGP), i.e. the beginning of the most critical period for the definition of the number of grains (Fischer, 1985; Abbate et al., 1997), was recorded when the average size of the spikes of the main shoots was $3 \mathrm{~cm}$. Above-ground crop dry weight (DW) was measured at seven days post anthesis (A7). Green area index was calculated as in Abbate et al. (2004), i.e. was determined by measuring the surface (one side) of all green organs (leaves, stems and spikes) with an area meter LI-3000 (LI-COR, Lincoln, Nebraska, USA) and the dry weight, of a crop subsample. After anthesis, the number of spikes was counted to determine the number of spikes per unit area. After physiological maturity (PM), $1.5 \mathrm{~m}^{2}$ of crop was harvest for determined above-ground crop DW, grain 
yield $\left(\mathrm{g} \mathrm{m}^{-2}\right)$ and the weight $(\mathrm{g})$ of two samples of 500 grains each; thus, the weight per grain and the number of grains $\mathrm{m}^{-2}$ were calculated. All samples were oven-dried until constant weight.

\section{Soybean measurements}

Primary development stages were determined as described by Fehr and Caviness (1977). Above-ground DW of crops was measured at three times; at wheat harvest (WH), at beginning of grain filling (R5) and after PM (R7). A sub sample was dissected into leaf laminas, stems (with leaf stalk) and pods. Leaf area index was calculated at $\mathrm{WH}$ and R5 by measuring the surface of all green leaf laminas of a subsample with an area meter LI-3000, and its dry weight. After PM, $1.5 \mathrm{~m}^{2}$ of crop was harvest for determined DW, grain yield $\left(\mathrm{g} \mathrm{m}^{-2}\right)$, weight per grain $(\mathrm{g})$ and the number of grains $\mathrm{m}^{-2}$ was determined. All samples were oven-dried until constant weight. Crop growth rate ( $C G R, \mathrm{~g} \mathrm{~m}^{-2}$ day) was calculated for the period of WH and $\mathrm{R} 5$ as the quotient between the increase in DW and the interval (days) between samplings.

\section{Light interception measurements}

Photosynthetic active radiation $(P A R)$ transmission profiles were measured at midday on each plot approximately every 15 days, considering $P A R$ as $50 \%$ of total radiation. In wheat, $P A R$ measurements were performed from stage DC30 (Zadoks et al., 1974) to A7, and in soybean from WH to PM, using a LI-COR 191 SB (LICOR, Lincoln, Nebraska, USA). Because the distance between rows was not regular and the percentage of intercepted radiation $(R i)$ was low during a large part of the crop cycle, a particular method for computing of $R i$ was used. $P A R$ measurements were taken placing the sensor across a sequence of rows corresponding for each treatment (Fig. 1). In each plot, measurements were made at ground level $(I)$ and at the top of the canopy (Io). The $R i$ was calculated as:

$$
R i=(1-I / I o)
$$

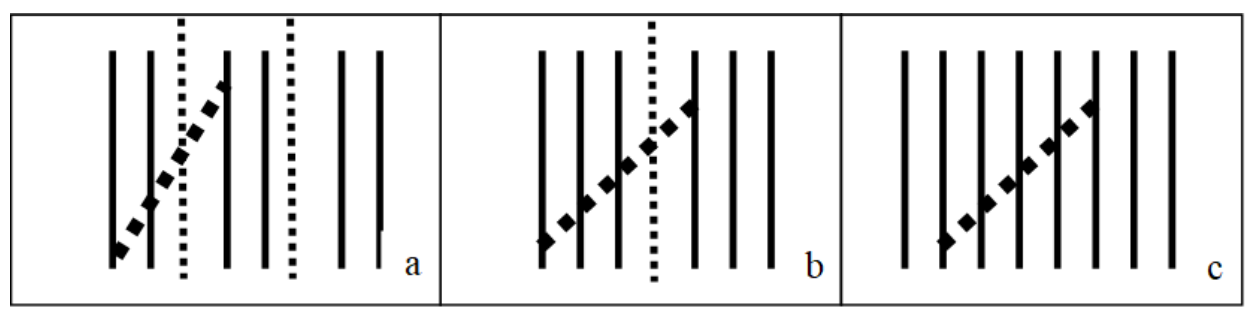

Fig. 1. Planting patterns for (a) "2:1" treatments $T 1$, $T 4$ and T5; (b) "3:1" T2 and (c) "1:0" T3 all rows planted with wheat ( $17.5 \mathrm{~cm}$ row distance). Solid lines represent wheat rows and broken lines soybean rows. Soybean row distance in T1, T4 and T5 (a) was $52.5 \mathrm{~cm}$ and for T2 (b) was $70 \mathrm{~cm}$. Radiometer placement for light measurement is represented by a diagonal broken line.

The fraction of radiation intercepted at midday $\left(R i_{m}\right)$ was used to determine the fraction of intercepted radiation throughout the day $\left(R i_{p}\right)$, by an adjusted method based on the modification of equation proposed by CharlesEdwards and Lawn (1984):

$$
R i_{p}=\frac{a \times R i_{m}}{a-1+R i_{m}}
$$

This method consisted in adjusting the constant $a$ (Eq. 2) iteratively by comparing $R i_{p}$ estimated by Eq. 2 with a $R i_{p}$ observed. The $R i_{p}$ observed was measured at five times (8:30, 10:20, 11:50, 12:40 and 15:10 h), at stage CD50 for wheat and in $\mathrm{R} 5$ for soybean. Then, the $R i_{p}$ observed, weighted by the incident radiation at each times, was calculated as (Flénet, 1996): 


$$
R i_{p}=\frac{\sum_{h=1}^{h=n}\left(R i_{h} \times I o_{h}\right)}{\sum_{h=1}^{h=n}\left(I o_{h}\right)}
$$

where $R i_{h}$ is the fraction of $P A R$ intercepted (Eq. 1) measured at time $h$. For wheat the adjusted $a$ was 2.92 $\left(\mathrm{SE}=1.81 \% ; \mathrm{r}^{2}=0.72\right)$ and for soybean was $2.76\left(\mathrm{SE}=3.54 \%, \mathrm{r}^{2}=0.92\right)$. This adjustment values were used at other days of $R i_{m}$ for estimate $R i_{p}$. The $R i_{p}$ for days between measurements was estimates by linear interpolation between measurements.

Intercepted $P A R$ (PARi, MJ $\mathrm{m}^{-2}$ day $^{-1}$ ) was calculated as the product between $R i_{p}$ and daily incident $P A R$. Radiation use efficiency $\left(R U E, \mathrm{~g} \mathrm{MJ}^{-1}\right)$ was calculated as the ratio between $C G R$ and mean intercepted $P A R$ among samples.

\section{Results}

\section{Wheat}

Hotter and drier conditions on the second experiment reduced the grain-filling period (A7 to PM). However, the treatments did not affect wheat development stages in any year (data not shown). With similar grain numbers per unit area between years, the better conditions for grain filling in the first experiment (water and cooler temperatures) increased yield by high weight per grain (Tables 1 and 2). Wheat at both intercropping planting patterns had similar performance, but both yielded $11 \%$ below the treatment with all rows planted (Table 2). Similar effects were found in grains $\mathrm{m}^{-2}$ and spikes $\mathrm{m}^{-2}$; however, intercropping systems did not change the number of grains per spike ${ }^{-1}$ and the weight per grain (Table 2). Yield was directly associated with grains $\mathrm{m}^{-2}$ $\left(r^{2}=0.84 ; p<0.001\right)$ and spikes $m^{-2}\left(r^{2}=0.63 p<0.001\right)$.

Table 1. Meteorological conditions and wheat phenology: sowing (S); emergency (E); beginning of the period of growth of the spikes, i.e. when the average size of the spikes of the main shoots was $3 \mathrm{~cm}$ (BSGP); seven days after anthesis (A7) and physiological maturity (MF).

\begin{tabular}{|c|c|c|c|c|c|}
\hline \multirow{2}{*}{ Variable } & \multirow{2}{*}{ Year } & \multicolumn{4}{|c|}{ Phenology phase } \\
\hline & & S to $E$ & E to TN & BSGP to A7 & A7 to FM \\
\hline \multirow{2}{*}{ Date } & 2003 & 17-Jul / 04-Ago & 04-Ago / 25-Oct & 25-Oct / 25-Nov & 25-Nov / 24-Dec \\
\hline & 2004 & 07-Jul / 26-Jul & 26-Jul / 20-Oct & 20-Oct / 23-Nov & 23-Nov / 16-Dec \\
\hline \multirow{2}{*}{ Duration (d) } & 2003 & 18 & 82 & 31 & 29 \\
\hline & 2004 & 19 & 86 & 34 & 23 \\
\hline \multirow{2}{*}{$\begin{array}{l}\text { Thermal time }\left({ }^{\circ} \mathrm{Cd}\right) \\
\text { (temp. base } 4.5^{\circ} \mathrm{C} \text { ) }\end{array}$} & 2003 & 83.3 & 546 & 350 & 395 \\
\hline & 2004 & 83.3 & 577 & 354 & 358 \\
\hline \multirow{2}{*}{ Precipitation (mm) } & 2003 & 52.5 & 194 & 106 & 133 \\
\hline & 2004 & 77.3 & 201 & 74 & 42 \\
\hline \multirow{2}{*}{$\begin{array}{c}\text { Incident Radiation } \\
\left(\mathrm{MJ} \mathrm{m}^{-2}\right)\end{array}$} & 2003 & 116 & 968 & 658 & 657 \\
\hline & 2004 & 121 & 972 & 635 & 499 \\
\hline
\end{tabular}

Similarly to that observed for yield, above-ground DW at stages A7 and PM was similar between intercropping patterns and different to conventional planting (Table 3). Equivalent results were found in the PARi during spike growth period (i.e. BSGP-A7 phase, Table 3). However, RUE did not change between intercrop and conventional planting pattern (Table 3). During spike growth period, the $P A R i$ was strongly associated with mean $R i_{p}\left(r^{2}=0.95\right.$, 
$\mathrm{p}<0.001$ ), showing that the effect of the treatments on PARi could be explained through changes in $R i_{p}$ (Table $3)$.

Table 2. Yield, grain numbers $\mathrm{m}^{-2}$, weight per grain, spikes $\mathrm{m}^{-2}$ and grains per spike in wheat as function of planting pattern and year. Means followed by the same letter within a column are not significantly different at $\mathrm{P}<0.05$ ( $\mathrm{F}$ test).

\begin{tabular}{|c|c|c|c|c|c|}
\hline \multirow{2}{*}{ Treatment } & Yield & Grain number & Weight per grain & Spikes number & Grains \\
\cline { 2 - 6 } & $\left(\mathrm{g} \mathrm{m}^{-2}\right)$ & $\left(\right.$ grains $\left.^{-2}\right)$ & $(\mathrm{mg})$ & $\left(\right.$ spikes $\left.\mathrm{m}^{-2}\right)$ & $\left(\right.$ grains spike $\left.^{-1}\right)$ \\
\hline T1 $(2: 1)$ & $639^{\mathrm{a}}$ & $17387^{\mathrm{a}}$ & $36.7^{\mathrm{a}}$ & $587^{\mathrm{a}}$ & $30.0^{\mathrm{a}}$ \\
\hline T2 $(3: 1)$ & $635^{\mathrm{a}}$ & $17200^{\mathrm{a}}$ & $36.9^{\mathrm{a}}$ & $576^{\mathrm{a}}$ & $30.0^{\mathrm{a}}$ \\
\hline T3 $(1: 0)$ & $716^{\mathrm{b}}$ & $19441^{\mathrm{b}}$ & $36.8^{\mathrm{a}}$ & $629^{\mathrm{b}}$ & $31.0^{\mathrm{a}}$ \\
\hline Year 1 & $717^{\mathrm{a}}$ & $18638^{\mathrm{a}}$ & $38.5^{\mathrm{a}}$ & $607^{\mathrm{a}}$ & $30.8^{\mathrm{a}}$ \\
\hline Year 2 & $610^{\mathrm{b}}$ & $17381^{\mathrm{a}}$ & $35.1^{\mathrm{b}}$ & $581^{\mathrm{a}}$ & $29.9^{\mathrm{a}}$ \\
\hline Treat. $\mathbf{x}$ Year & $\mathrm{ns}$ & $\mathrm{p}=0.007$ & $\mathrm{~ns}$ & $\mathrm{~ns}$ & $\mathrm{p}=0.04$ \\
\hline \multicolumn{7}{|c|}{ standard error of one means } & \\
\hline Treatment & 19.9 & 597.8 & 0.25 & 19.3 & 0.7 \\
\hline Treat. x Year 1 & 24.5 & 756.7 & 0.28 & 22.4 & 0.35 \\
\hline Treat. x Year 2 & 28.3 & 873.7 & 0.33 & 25.8 & 0.4 \\
\hline
\end{tabular}

Table 3. Descriptive variables of wheat growth as function of planting pattern and year. Above-ground dry weight (DW) at seven days after anthesis (A7) and after physiological maturity (PM); photosynthetic active radiation intercepted $(P A R i)$ and average of the fraction of intercepted radiation during all the day $\left(R i_{p}\right)$, between the beginning of the period of growth of the spikes (BSGP; i.e. when the average size of the spikes of the main shoots was $3 \mathrm{~cm}$ ) and $A 7$; mean radiation use efficiency (RUE) between BSGP and A7; green area index (GAI) at A7; grain number (M) per unit of above-ground dry mater at $A 7$; harvest index ( $\mathrm{HI})$. Means followed by the same letter within a column are not significantly different at $\mathrm{P}<0.05$ ( $F$ test).

\begin{tabular}{|c|c|c|c|c|c|c|c|c|}
\hline \multirow{3}{*}{ Treatment } & DW & DW & PARi & Rip & RUE & GAI & GN/DW & HI \\
\cline { 2 - 10 } & A7 & FM & BSGP-A7 & BSGP-A7 & A7 & A7 & A7/FM & FM \\
\cline { 2 - 10 } & $\left(\mathrm{g} \mathrm{m}^{-2}\right)$ & $\left(\mathrm{g} \mathrm{m}^{-2}\right)$ & $\left(\mathrm{MJ} \mathrm{m}^{-2}\right)$ & $(\%)$ & $\left(\mathrm{g} \mathrm{MJ}^{-1}\right)$ & $\left(\mathrm{m}^{2} \mathrm{~m}^{-2}\right)$ & $\left(\mathrm{grains}^{-1}\right)$ & $\left(\mathrm{g} \mathrm{g}^{-1}\right)$ \\
\hline T1 $(2: 1)$ & $1108^{\mathrm{a}}$ & $1606^{\mathrm{a}}$ & $265^{\mathrm{a}}$ & $82^{\mathrm{a}}$ & $2.77^{\mathrm{a}}$ & $5.6^{\mathrm{a}}$ & $15.7^{\mathrm{a}}$ & $39.9^{\mathrm{a}}$ \\
\hline T2 $(3: 1)$ & $1139^{\mathrm{a}}$ & $1583^{\mathrm{a}}$ & $272^{\mathrm{a}}$ & $84^{\mathrm{a}}$ & $2.72^{\mathrm{a}}$ & $5.6^{\mathrm{a}}$ & $15.1^{\mathrm{a}}$ & $40.2^{\mathrm{a}}$ \\
\hline T3 $(1: 0)$ & $1238^{\mathrm{b}}$ & $1752^{\mathrm{b}}$ & $294^{\mathrm{b}}$ & $91^{\mathrm{b}}$ & $2.60^{\mathrm{a}}$ & $6.6^{\mathrm{b}}$ & $15.7^{\mathrm{a}}$ & $41.1^{\mathrm{a}}$ \\
\hline Year 1 & $1221^{\mathrm{a}}$ & $1658^{\mathrm{a}}$ & $285^{\mathrm{a}}$ & $87^{\mathrm{a}}$ & $2.86^{\mathrm{a}}$ & $7.5^{\mathrm{a}}$ & $15.3^{\mathrm{a}}$ & $43.4^{\mathrm{a}}$ \\
\hline Year 2 & $1102^{\mathrm{a}}$ & $1636^{\mathrm{a}}$ & $269^{\mathrm{a}}$ & $85^{\mathrm{a}}$ & $2.54^{\mathrm{a}}$ & $4.3^{\mathrm{b}}$ & $15.7^{\mathrm{a}}$ & $37.4^{\mathrm{b}}$ \\
\hline T x Y & $\mathrm{ns}$ & $\mathrm{ns}$ & $\mathrm{ns}$ & $\mathrm{ns}$ & $\mathrm{ns}$ & $\mathrm{ns}$ & $\mathrm{ns}$ & $\mathrm{ns}$ \\
\hline \multicolumn{7}{|c|}{ Standard error of the mean } & & \\
\hline Treatment & 34 & 74 & 4.5 & 1.4 & 0.1 & 0.3 & 0.44 & 0.85 \\
\hline Treat. x Year 1 & 41 & 89 & 4.6 & 1.6 & 0.1 & 0.3 & 0.42 & 0.89 \\
\hline Treat. x Year 2 & 48 & 103 & 5.3 & 1.9 & 0.1 & 0.3 & 0.49 & 1.03 \\
\hline
\end{tabular}

Planting patterns did not affect the harvest index nor grain number per unit above-ground DW at A7, as an indicator of spike fertility. Then, yield was better associated with DW after FM $\left(r^{2}=0.50 ; p<0.001\right)$ than with harvest index $\left(r^{2}=0.19 ; p=0.053\right)$. Furthermore, when deleting year effects by linear regression between yield 
residuals and DW residuals, the association was clearly high $\left(r^{2}=0.83 ; p<0.001\right)$. Moreover, by the same residual relationship, yield was not associated with harvest index $\left(r^{2}=0.11 ; p<0.14\right)$.

Grains $\mathrm{m}^{-2}$ was associated with $P A R i$ between stages BSGP and A7, with DW at A7 and with DW after PM $\left(\mathrm{r}^{2}=0.71\right.$; $r^{2}=0.54 ; r^{2}=0.74 ; p<0.001$; respectively). Thus, differences between treatments and variable relationships prove that planting patterns affected wheat yield mainly through differences in crop growth, without great effects in growth distribution.

\section{Soybean}

Abundant rain and low temperatures prolonged the period of coexistence of crops during the first experiment more than in the second (Table 4). However, after WH, the meteorological difference between years was lower (Table 4). Soybean phenology was affected by year and treatment. A greatest amplitude between stages R1 and R5 was done in the first experiment ( 34 vs. $27 d ; p=0.01$ ). The stress by intercropping systems produced an increase in the soybean cycle length. The total cycle was longer in rainfed relay intercropping (118 $d$, treatment T1), intermediate in irrigated relay intercropping (112 d, T4) and shorter for irrigated soybean without wheat (107 d, T5). The main effect of WS was evident when rainfed soybean (T1) showed a delay in the beginning of pod stage (R3) as compared to the irrigated treatments, induced by abortion of earlier-anthesed flowers (data not show). As consequence, the period R1-R5 was increase by effect of WS (Fig. 2).

Table 4. Meteorological conditions and soybean phenology: sowing (S), emergence (E), wheat harvest (WH), beginning of grain filling (R5) and physiological maturity (R7).

\begin{tabular}{|c|c|c|c|c|c|}
\hline \multirow{2}{*}{ Factor } & & \multicolumn{4}{|c|}{ Phenology } \\
\hline & & $S$ to $E$ & E to WH & WH to R5 & R5 to $\mathrm{R7}$ \\
\hline \multirow{2}{*}{ Date } & $2003 / 04$ & $\begin{array}{c}\text { 29-Nov/ 07- } \\
\text { Dec }\end{array}$ & $\begin{array}{l}\text { 07-Dec/ 08- } \\
\text { Ene }\end{array}$ & $\begin{array}{c}\text { 09-Jan/ 03- } \\
\text { Mar }\end{array}$ & $\begin{array}{c}\text { 03-Mar/ 30- } \\
\text { Mar }\end{array}$ \\
\hline & $2004 / 05$ & $\begin{array}{c}\text { 02-Dic/ 09- } \\
\text { Dec }\end{array}$ & $\begin{array}{l}\text { 09-Dec/ 06- } \\
\text { Ene }\end{array}$ & $\begin{array}{c}\text { 06-Jan/ } 01- \\
\text { Mar }\end{array}$ & $\begin{array}{c}\text { 01-Mar/ 29- } \\
\text { Mar }\end{array}$ \\
\hline \multirow{2}{*}{ Duration (d) } & $2003 / 04$ & 8 & 33 & 54 & 27 \\
\hline & $2004 / 05$ & 7 & 28 & 54 & 28 \\
\hline \multirow{2}{*}{$\begin{array}{l}\text { Thermal time }\left({ }^{\circ} \mathrm{Cd}\right) \\
\text { (temp. base } 8^{\circ} \mathrm{C} \text { ) }\end{array}$} & $2003 / 04$ & 84 & 368 & 666 & 367 \\
\hline & $2004 / 05$ & 84 & 370 & 682 & 331 \\
\hline \multirow{2}{*}{$\begin{array}{c}\text { Average air } \\
\text { temperature }\left({ }^{\circ} \mathrm{C}\right)\end{array}$} & $2003 / 04$ & 16.4 & 19.1 & 20.1 & 20.1 \\
\hline & $2004 / 05$ & 18.5 & 21.1 & 20.4 & 18.4 \\
\hline \multirow{2}{*}{ Precipitation (mm) } & $2003 / 04$ & 72 & 89 & 150 & 20 \\
\hline & $2004 / 05$ & 21 & 51 & 135 & 91 \\
\hline \multirow{2}{*}{ 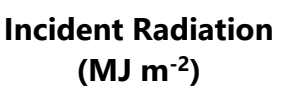 } & $2003 / 04$ & 199 & 720 & 1087 & 446 \\
\hline & $2004 / 05$ & 145 & 647 & 1091 & 523 \\
\hline
\end{tabular}




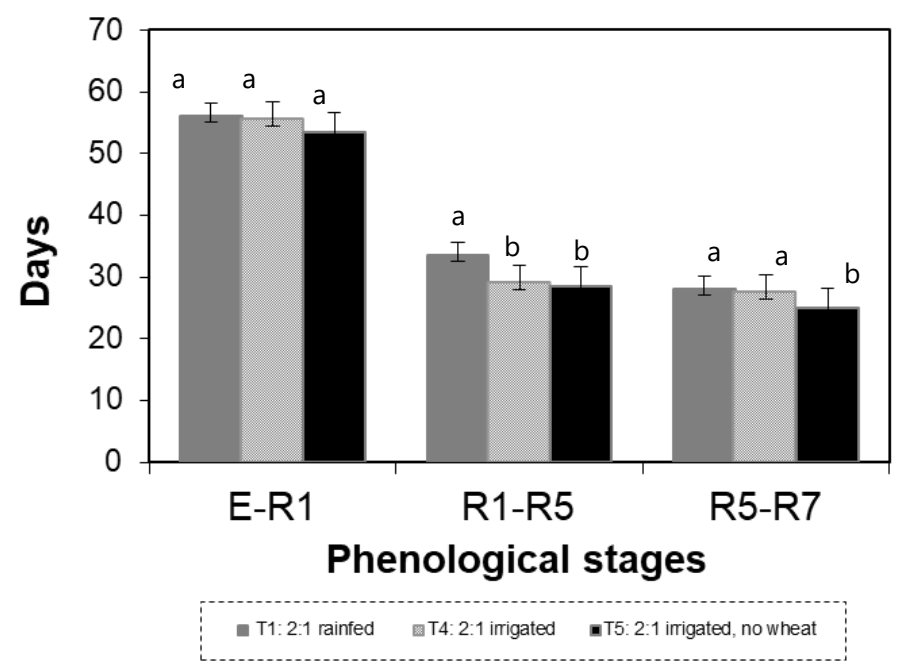

Fig. 2. Length of different phenological stages of soybean as function of soybean planting pattern. Average of two years. Means followed by the same letter within a period are not significantly different at $\mathrm{P}<0.05$ ( $F$ test).

Significant yield differences were found between treatments (Table 5); the most relevant of these differences were: (i) at narrow row distance $(52 \mathrm{~cm})$, rainfed intercropped soybean obtained a $23 \%$ better yield respect to wide row distance $(70 \mathrm{~cm}$ ); (ii) irrigated intercropped soybean (treatment T4) yielded more than rainfed soybean (T1), showing the important effect of water stress on yield (WS=63\%); and (iii) irrigated intercropping soybean (treatment T4) yielded less than irrigated non-intercropping soybean (T5), showing that the effects of OSF caused the remaining $37 \%$ yield decrease by relay intercropping system.

Similarly to that founded for yield, differences were observed between treatments in grains $\mathrm{m}^{-2}$ (Table 5) and these variables were strongly associated $\left(r^{2}=0.98 ; p<0.001\right)$. Significant Treatment $x$ Year interaction occurred in yield and grains $\mathrm{m}^{-2}$ (Table 5). However, the interaction did not present a crossing in the effect of the treatments between experiments. At rainfed intercropping, soybean row spacing did not affect weight per grain (Table 5); however, similar to grain $\mathrm{m}^{-2}$, WS decreased grain per grain by $60 \%$ whereas OSF decreased it by $40 \%$. When the year effect was removed, weight per grain was positively related to grain numbers $\mathrm{m}^{-2}\left(r^{2}=0.52 ; \mathrm{p}<0.001\right)$. Thus, stress induced by wheat affected yield components of soybean more for WS than for OSF (Table 5).

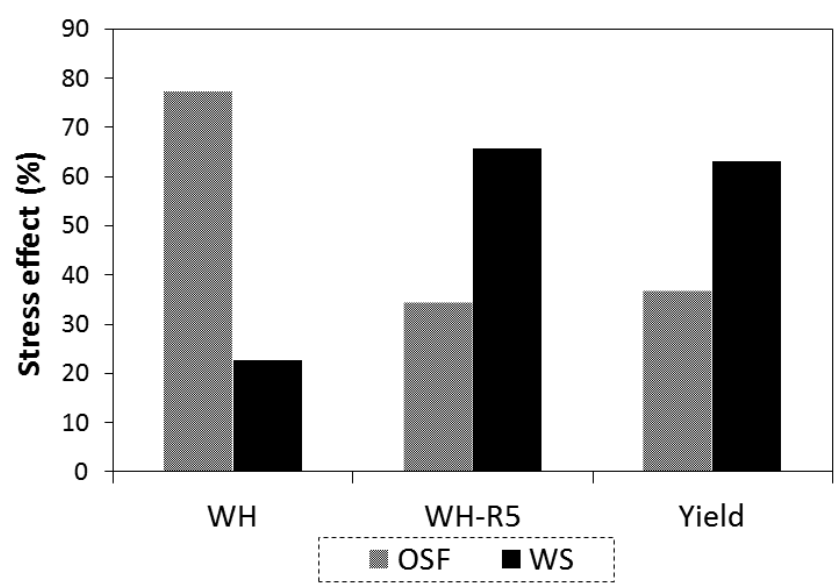

Fig. 3. Wheat effects on intercropped soybean: water stress (WS; eq. 2) and other stress factors (OSF; eq. 3) in above-ground dry weight at wheat harvest $(\mathrm{WH})$, in crop growth rate between $\mathrm{WH}$ and $\mathrm{R} 5$ and in grain yield. For each variable the effects of WS and OSF were statistically different according to $F$ test; $p<0.05$ (Table 5 and 6). 
Table 5. Yield, grains numbers $\mathrm{m}^{-2}$ and weight per grain, and effect of water Stress (WS, Eq. $2_{2}$ ) and other stress factors (OSF, Eq. 3), in soybean as function of planting pattern and year. Means followed by the same letter within a column are not significantly different at $\mathrm{P}<0.05$ ( $\mathrm{F}$ test).

\begin{tabular}{|c|c|c|c|}
\hline Treatment & Yield $\left(\mathrm{g} \mathrm{m}^{-2}\right)$ & $\begin{array}{l}\text { Grains } \mathbf{m}^{-2} \\
{\text { (grains } \mathrm{m}^{-2} \text { ) }}\end{array}$ & $\begin{array}{c}\text { Weight per grain } \\
(\mathrm{mg})\end{array}$ \\
\hline T1: 2/1 (rainfed) & $166^{a}$ & $1100^{\mathrm{a}}$ & $151^{\mathrm{a}}$ \\
\hline T2: 3/1 (rainfed) & $127^{b}$ & $838^{b}$ & $153^{\mathrm{a}}$ \\
\hline T4: 2/1 (irrigated) & $281^{\mathrm{c}}$ & $1696^{c}$ & $166^{b}$ \\
\hline T5: 2/1 (irrigated, no wheat) & $348^{d}$ & $1983^{d}$ & $176^{c}$ \\
\hline Year 1 & $257^{a}$ & $1590^{a}$ & $158^{\mathrm{a}}$ \\
\hline Year 2 & $204^{b}$ & $1218^{b}$ & $165^{b}$ \\
\hline Treat $x$ Year & $p=0.02$ & $p=0.04$ & ns \\
\hline \multicolumn{4}{|c|}{ Standard error of the mean } \\
\hline Treatment & 10.6 & 62 & 3.1 \\
\hline Trat. x Year 1 & 10.4 & 61 & 1.9 \\
\hline Trat. x Year 2 & 12 & 71 & 2.2 \\
\hline WS & 33 & 67 & 60 \\
\hline OSF & 37 & 33 & 40 \\
\hline
\end{tabular}

All growth variables measured were significantly decreased by WS and by OSF, but OSF did not affect RUE (Table 6). At WH, the effect on above-ground DW of OSF was more important than that of WS (Fig 3). However, between $\mathrm{WH}$ and R5, WS was predominant in decreasing the CGR, similarly to that observed for yield (Fig 3). The significant effect of WS on growth and yield took place by decreasing both $R i_{p}$ and $R U E$ (Table 6). At rainfed treatments, row spacing did not show a significant effect in above-ground DW nor CGR (Table 6). However, when row spacing was increased of 52 to $70 \mathrm{~cm}$, like wheat, for soybean we found differences only in $R i_{p}$ and PARi (Table 6). The CGR was associated with PARi between WH and R5 $\left(r^{2}=0.76 ; p<0.001\right)$; moreover, the PARi during this period was strongly related with the $R i_{p}\left(r^{2}=0.99 ; p<0.001\right)$.

During the critic period of soybean yield determination (R1-R5) (Andrade et al., 2010) WS, OSF and row spacing affected the amount PARi (Table 6). This variable was associated with the $R i_{p}\left(r^{2}=0.54 ; p<0.001\right)$, without a clear association with incident radiation $\left(r^{2}=0.02 ; p=0.8\right)$ nor with the duration of the period $\left(r^{2}=0.60 ; p=0.01\right)$. Furthermore, removing the year effect by residual relationship, PARi between stages R 1 to R5 was strongly related to $R i_{p}\left(\mathrm{r}^{2}=0.94 ; \mathrm{p}<0.001\right)$. The evolution of the $R i_{p}$ was affected by treatments in a similar way to that observed for the growth variables (Table 6, Fig. 4). We found less $R i_{p}$ during the stages R1to R5 in the first experiment than during the second experiment, but the greatest amplitude in the first experiment (34 vs. $27 \mathrm{~d}$; $\mathrm{p}<0.05$ ) determined more PARi (Table 6). This better PARi between stages R1 to R5 was linked with more grains $\mathrm{m}^{-2}$ in the first experiment (Table 6 and 5 respectively).

Several statistical associations were found between yield component and crop variables. The closest relationships were between yield and grain number $\mathrm{m}^{-2}$ with $C G R$ during WH to $\mathrm{R} 5\left(\mathrm{r}^{2}=0.84 ; \mathrm{r}^{2}=0.81 ; \mathrm{p}<0.001\right.$; respectively) and with total DW at $R 5\left(r^{2}=0.85 ; r^{2}=0.82 ; p<0.001\right.$; respectively), and pod with the $C G R$ between stages WH to R5 ( $r^{2}=0.92 ; \mathrm{p}<0.001 ;$ Fig. 5). Finally, grains $\mathrm{m}^{-2}$, as a first yield determinant, was related to PARi between stages $R 1$ to $R 5\left(r^{2}=0.85 ; p<0.001\right)$, but was not significantly affected by the duration of the period $\left(r^{2}=0.02 ; p=0.49\right)$. 
Table 6. Descriptive variables of soybean growth as function of planting pattern and year. Above-ground dry weight (DW) at wheat harvest (WH) and beginning of grain filling (R5); crop growth rate (CGR) between WH and $\mathrm{R} 5$; specific leaf area (SLA) at WH; pods dry weight (PDW) at R5; leaf area index (LAI) at R5; photosynthetic active radiation intercepted (PARi) between $\mathrm{WH}$ and $\mathrm{R} 5$, and beginning of flowering (R1) and R5; radiation use efficiency (RUE) between WH and R5; average daily radiation interception efficiency $\left(R i_{p}\right)$ between R1 and R5; harvest index $(\mathrm{HI})$ after physiological maturity (R7). Means followed by the same letter within a column are not significantly different at $\mathrm{P}<0.05$ ( $\mathrm{F}$ test).

\begin{tabular}{|c|c|c|c|c|c|c|c|c|c|c|c|}
\hline \multirow{3}{*}{ Treatments } & \multicolumn{2}{|c|}{ WH } & \multicolumn{3}{|c|}{ R5 } & \multicolumn{3}{|c|}{ WH-R5 } & \multicolumn{2}{|c|}{ R1-R5 } & \multirow{2}{*}{$\begin{array}{l}\text { R7 } \\
\text { HI * }\end{array}$} \\
\hline & DW & SLA & DW & PDW & LAI & CGR & PARi & RUE & PARi & $R i_{p}$ & \\
\hline & $\mathrm{g} \mathrm{m}^{-2}$ & $\mathrm{~cm}^{2} \mathrm{~g}^{-1}$ & \multicolumn{2}{|c|}{$\mathrm{g} \mathrm{m}^{-2}$} & $m^{2} m^{-2}$ & $\mathrm{~g} \mathrm{~m}^{-2} \mathrm{~d}^{-1}$ & $M j m^{-2}$ & $\mathrm{~g} \mathrm{Mj}^{-1}$ & $\mathrm{Mj} \mathrm{m}^{-2}$ & $\%$ & $\%$ \\
\hline T1: 2/1 (rainfed) & $18.3^{\mathrm{a}}$ & $377^{a}$ & $231^{a}$ & $40.3^{a}$ & $2.02^{\mathrm{a}}$ & $3.86^{a}$ & $222^{a}$ & $0.95^{\mathrm{a}}$ & $175^{a}$ & $60^{a}$ & $54.6^{\mathrm{a}}$ \\
\hline T2: 3/1 (rainfed) & $17.4^{\mathrm{a}}$ & nd & $176^{a}$ & $25.9^{a}$ & $1.58^{a}$ & $2.90^{\mathrm{a}}$ & $185^{b}$ & $0.86^{a}$ & $145^{b}$ & $49^{b}$ & $53.6^{a}$ \\
\hline T4: 2/1 (irrigated) & $33.7^{\mathrm{b}}$ & $496^{b}$ & $518^{b}$ & $102.2^{b}$ & $4.08^{b}$ & $8.80^{\mathrm{b}}$ & $345^{c}$ & $1.39^{b}$ & $208^{c}$ & $80^{c}$ & $54.1^{\mathrm{a}}$ \\
\hline $\begin{array}{c}\text { T5: } 2 / 1 \text { (irrigated, } \\
\text { no wheat) }\end{array}$ & $86.5^{\mathrm{c}}$ & $325^{c}$ & $710^{c}$ & $146.9^{c}$ & $5.02^{c}$ & $11.38^{\mathrm{c}}$ & $468^{d}$ & $1.34^{\mathrm{b}}$ & $246^{d}$ & $93^{d}$ & $50.6^{b}$ \\
\hline Year 1 & $46.0^{\mathrm{a}}$ & $538^{a}$ & $442^{a}$ & $91.6^{\mathrm{a}}$ & $3.4^{\mathrm{a}}$ & $7.34^{\mathrm{a}}$ & $285^{a}$ & $1.26^{\mathrm{a}}$ & $208^{a}$ & $63^{a}$ & $56.2^{\mathrm{a}}$ \\
\hline Year 2 & $31.9^{b}$ & $260^{b}$ & $375^{a}$ & $66.1^{\mathrm{b}}$ & $2.95 a$ & $6.13^{a}$ & $327^{b}$ & $1.00^{\mathrm{b}}$ & $179^{b}$ & $77^{\mathrm{b}}$ & $50.2^{b}$ \\
\hline Treat $\mathrm{x}$ Year & ns & $p<0.01$ & $p<0.01$ & ns & $p<0.01$ & $p<0.01$ & ns & $p=0.01$ & ns & ns & ns \\
\hline \multicolumn{12}{|c|}{ Standard error of the mean } \\
\hline Treatment & 4.2 & 9.8 & 29.5 & 7.8 & 0.23 & 0.51 & 12 & 0.06 & 8 & 2.7 & 0.62 \\
\hline Trat. x Year 1 & 3.4 & 9.8 & 28.6 & 6.8 & 0.2 & 0.47 & 9 & 0.05 & 5.7 & 1.7 & 0.45 \\
\hline Trat. x Year 2 & 3.4 & 9.3 & 28.6 & 6.8 & 0.2 & 0.47 & 9 & 0.05 & 5.7 & 1.7 & 0.52 \\
\hline
\end{tabular}

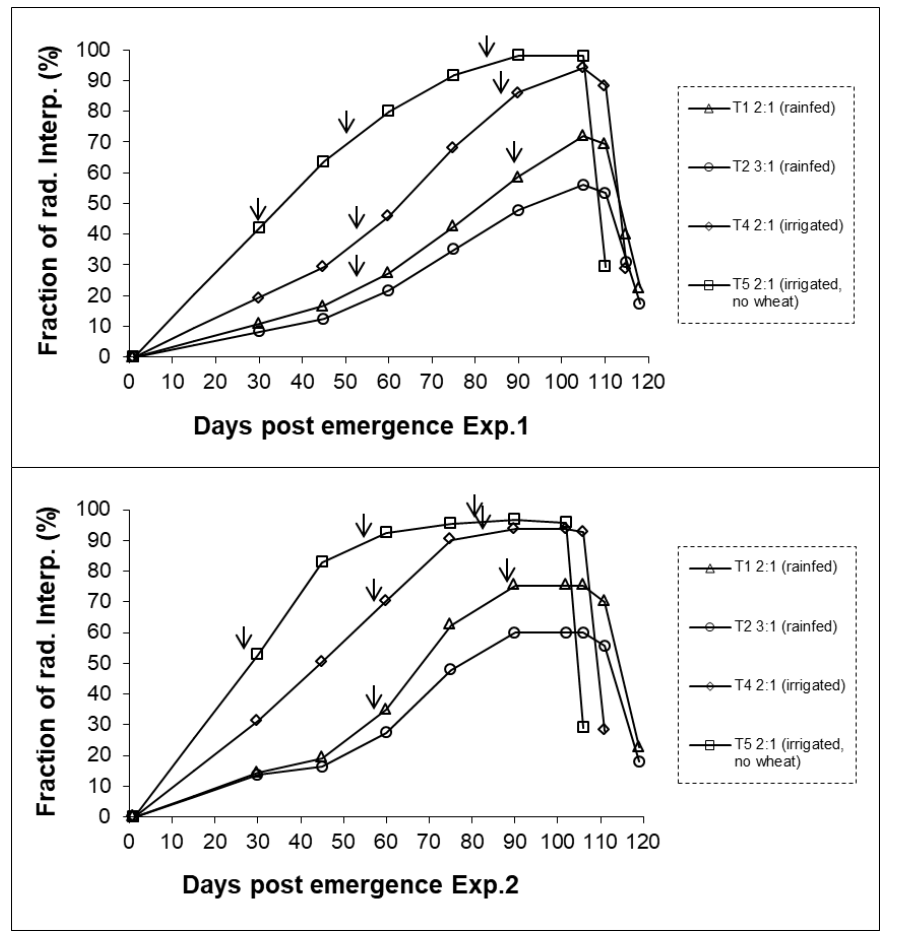

Fig. 4. Average proportion of daily radiation interception (Rip) as function of days post emergence for four soybean planting pattern, in two growth seasons. Arrows indicate: wheat harvest, beginning of flowering (R1) and beginning of grain filling (R5) stages. 


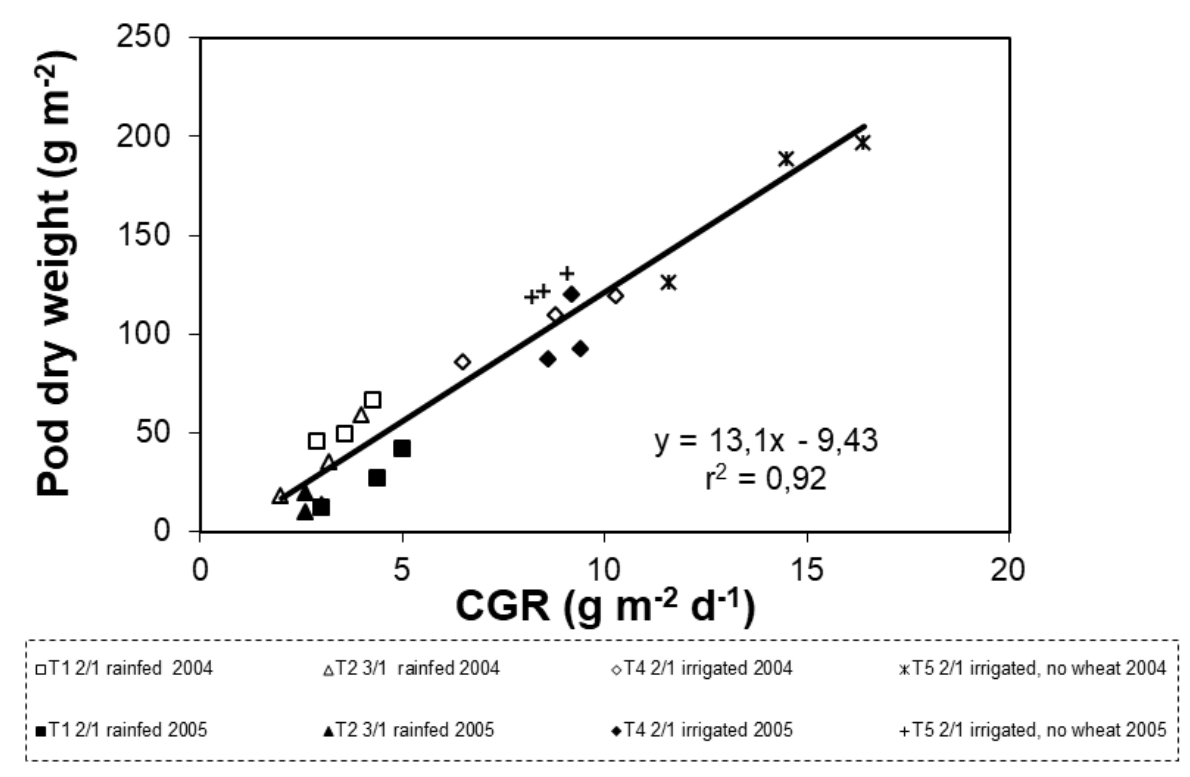

Fig. 5. Pod dry weight in R5 as function of crop growth rate (CGR) between wheat harvest and R5 for soybean planting pattern.

\section{Discussion}

\section{Wheat}

Both intercrop patterns (2:1 y 3:1) yielded $11 \%$ less than wheat at normal planting (1:1). Similar results were reported in most wheat studies, where changes in seed rate or row spacing affected yield, primarily by changes in grains $\mathrm{m}^{-2}$ (Puckridge and Donald, 1967; Fischer, 1976; Darwinkel, 1978; Tompkins et al., 1991). If, it is considered that wheat growth 20-30 days before grain filling is critical for grain establishment (Fischer, 1985; Abbate et al., 1997), crop conditions in this period can explain yield differences if grains have similar weight. Accumulated DW for crops has been described as the product between PARi and RUE (Monteith and Moss, 1977; Gallagher and Biscoe, 1978; Fischer, 1985; Abbate et al., 1997). At our work, planting patterns not affect the RUE (Table 3) and grain numbers per unit area was associated with PARi between BSGP to A7. However, a previous study carry out in Balcarce did not find yield differences between conventional and intercropping patterns (Caviglia, 2005). The discrepancy between results can be attributed to differences in the wheat cultivar. Caviglia (2005) used the cultivar PROINTA Imperial, which is characterized by the ability to maintain high soil cover. This can be appreciated that, at the moment of maximum $R i_{p}$, Caviglia (2005)'s result show that wheat in intercrop reduced $5 \% R i_{p}$ compared to conventional planting, whereas in our work the difference was $10 \%$.

In intercropping systems, wheat exhibited a mechanism for yield compensation; this was the increase in the yield per linear meter (row) of 35 and 19\% with intercropping array the 2:1 and 3:1 ratio with respect to 1:0, without showing changes in yield spike ${ }^{-1}$. Despite this compensation, the absence of rows negatively affected the yield and its components. This effect explained why the loss of wheat yield was less than the loss of rows.

\section{Soybean}

Concurring with this study, in most of the previous works, soybean showed lower yields at intercropping systems than as a sole crop (Chan et al., 1980; Reinbott et al., 1987; Duncan and Schapaugh, 1997; Caviglia, 2005). However, Wallace et al. (1992), at a middle latitude $\left(34^{\circ} \mathrm{N}\right)$, did not obtain yield differences between intercropping and soybean sole crops. This divergence with our experiments was probably determined because our experiments had: (1) a longer period of crop coexistence from soybean sowing to wheat harvest (41 to 35 vs. 19 to $14 \mathrm{~d}$ ) which should have increased the competition of wheat over soybeans; (2) shorter soybean cycle 
(maturity group IV vs. VI) limiting the duration of the vegetative growth period; (3) during the growth cycle soybean received a precipitation of 331 to $298 \mathrm{~mm}$, which was notoriously less than the $600 \mathrm{~mm}$ received by Wallace et al. (1992)'s crops.

The effect of each type of stress changed throughout the soybean cycle. Other stress factors were more important that WS before $\mathrm{WH}$; however, WS was more important after WH and WS produced greater loss of yield than OSF (Fig. 3). These results are in agreement with Board and Harville (1998), who found that in Baton Rouge (USA), soybean growth between stages R1 to R5 was critical to determine grain number $\mathrm{m}^{-2}$ and yield. Previous studies where have demonstrated that the effect due to the amplitude of the R1-R5 period could have the same relevance as CGR on grain number $\mathrm{m}^{-2}$ (Egli and Bruening, 2000; Kantolic and Slafer, 2001; Calviño et al., 2003). At our work, grains numbers per unit area was linked with PARi between stage R1 to R5 $\left(r^{2}=0.85\right.$; $\mathrm{p}<0.001$ ). While, the effects of WS increase the length of R1-R5 period (Fig. 2), decreased $R i_{p}$ determined a low $P A R i$ and lower grain numbers $\mathrm{m}^{-2}$ (Table 6 and 5). Moreover, WS decrease the RUE in the period WH-R5 (Table 6); therefore, a longer R1-R5 period not lead advantage when growth conditions remain unfavorable.

Grain numbers per unit areas was the main yield component $\left(r^{2}=0.98 ; p<0.001\right)$ and was affected by WS, OSF and row distance (Table 5). Moreover, like Calviño et al. (2003) and Caviglia (2005) grain numbers in soybean at later sowings has been positively associated to weight per grain $\left(r^{2}=0.52 ; p<0.001\right)$. In later sowing the source of assimilates for grain filling usually is the most limiting factor of yield (Egli and Bruening, 2000). In agreement with that, in this work, grain numbers and weight per grain were simultaneously decreased with intercropping (Table 5), demonstrating that the effects of the stress (by water and other resources) had a significant effect on the source of assimilates for grain establishment and grain filling.

Accumulated DW has been described as a product between PARi and RUE (Monteith and Moss, 1977; Kiniry et al., 1989). Calviño et al. (2003) found a relationship between weight per grain and PARi between stages R5 and R7. However, link Leonard (1962), in our experiment OSF decreased weight per grain but not the amount of $P A R i$ during R5-R7 period. This behavior can be attributed to a lower accumulation of assimilates for remobilization due to a lower CGR between stages R1 and R5 (Tables 6). Growth between R1 and R5 is considered critical for grain establishment in soybean (Andrade et al., 2000). Our analysis proposes that soybean DW of pods at R5 is an indicator of the amount of assimilates that the crop partitions to flower growth and grain establishment. Thus, the main effect of intercropping on soybean yield was through lower CGR between WH and R5 (Table 6) determining lowers pod in R5 (Fig. 6), and lower grain numbers and grain mass at PM (Table 6).

Ours experiments shows that OSF induced by wheat affects the growth of soybean after WH (Table 6, Fig. 5). Without water deficiency, intercropping treatments increase soybean specific leaf area (Table 6). An increase in specific leaf area favors an increase in $R i_{p}$ and transpiration rate per unit leaf DW (Urosa and Ascencio, 1993). In addition, Bowes et al. (1972) found that a high specific leaf area in soybean was related to a small photosynthetic rate and small radiation saturation point. Then, the morphological and physiological adjustments to a new light situation after WH also affected soybean growth. During approximately 10 days after WH, plants showed signs of water deficit with high incident radiation at midday, even in the irrigated intercropping treatments. Moreover, the increase is specific leaf area was not enough to increase the $R i_{p}$ and the small $R i_{p}$ after WH was the main effect causing the next $C G R$ to be low (Fig. 4, Table 6).

\section{Conclusions}

In order to assess and identify the effect of wheat competition on soybean intercrop, a particular form of treatment design was employed to separate the effect by WS from the EOF effects of stress on soybean performance. Moreover, to optimize the wheat-soybean relay intercropping system at rainfed condition this experiment compared planting patterns. 
Wheat yield was affected by row spacing, intercropping patterns yielded $11 \%$ less than normal planting. However, the intercropping system with a narrower row spacing $(52 \mathrm{~cm})$ had an increase in soybean yield (23\%). At rainfed crops, row spacing affected grain set and yield, and these were associated with the amount of PARi at the critical period of grain establishment.

In relay intercropping soybean, the effect of water deficit prevailed during the critical period and decreased growth and yield. This is relevant information for similar areas as Balcarce because rainfall between soybean planting and stage R5 during the experiments was around the historical average (1971-99; beginning of December until the end of February $=277 \mathrm{~mm}$ ). Moreover, even in irrigated conditions intercropping soybean yield was decreased because of wheat competition and interference. This result indicates that wheat competition by light and resources different from water during early stages could not be reversed in subsequent crop stages, affecting soybean performance.

\section{References}

1. Abbate, P.E., Andrade, F.H., Culot, J.P., Bindraban, P., 1997. Grain yield in wheat: effects of radiation during spike growth period. Field Crops Research 54, 245-257.

2. Abbate, P.E., Dardanelli, J.L., Cantarero, M.G., Maturano, M., Melchiori, R.J.M., Suero, E.E., 2004. Climatic and water availability effects on water-use efficiency in wheat. Crop Science 44, 474-483.

3. Allen, R.G., Pereira, L.S., Raes, D., Smith, M., 1998. Crop evapotranspiration-Guidelines for computing crop water requirements-FAO Irrigation and drainage paper 56. FAO, Rome 300, D05109.

4. Andrade, F.H., Calviño, P., Cirilo, A., Barbieri, P., 2000. Bases para el manejo del Maíz, el Girasol and la Soja. Editorial Médica Panamericana S. A. Capitulo 1. 9-25. Capitulo 3. 61-96.

5. Andrade, F.H., Calvino, P., Cirilo, A., Barbieri, P., 2002. Yield responses to narrow rows depend on increased radiation interception. Agronomy Journal 94, 975-980.

6. Andrade, F.H. Abbate, P.E., Otegui, M.E., Cirilo, A.G., Cerrudo, A.A. 2010. Ecophysiological Bases for Crop Management. The Americas Journal of Plant Science and Biotechnology 4 (special issue 1), 23-34.

7. Board, J., Harville, B., 1998. Late-planted soybean yield response to reproductive source/sink stress. Crop Science 38, 763-771.

8. Bowes, G., Ogren, W., Hageman, R., 1972. Light Saturation, Photosynthesis Rate, RuDP Carboxylase Activity, and Specific Leaf Weight in Soybeans Grown Under Different Light Intensities 1. Crop Science 12, 77-79.

9. Broyden, C.G., 1965. A class of methods for solving nonlinear simultaneous equations. Mathematics of computation 19, 577-593.

10. Calviño, P., Sadras, V., Andrade, F., 2003. Development, growth and yield of late-sown soybean in the southern Pampas. European Journal of Agronomy 19, 265-275.

11. Caviglia, O.P., 2005. Intensificación de la agricultura en el sudeste bonaerense por la incorporación del doble cultivo trigo-soja. Dr. Sci. thesis, University of Mar del Plata (UNMdP), Balcarce, Buenos Aires, Argentina.

12. Caviglia, O.P., Sadras, V.O., Andrade, F.H., 2004. Intensification of agriculture in the south-eastern Pampas: I. Capture and efficiency in the use of water and radiation in double-cropped wheat-soybean. Field Crops Research 87, 117-129. 
13. Chan, L., Johnson, R., Brown, C., 1980. Relay Intercropping Soybeans into Winter Wheat and Spring Oats. Agronomy Journal 72, 35-39.

14. Charles-Edwards, D., Lawn, R., 1984. Light interception by grain legume row crops. Plant, Cell \& Environment 7, 247-251.

15. Darwinkel, A., 1978. Patterns of tillering and grain production of winter wheat at a wide range of plant densities. Netherlands Journal of Agricultural Science.

16. Draper, N., Smith, H., 1966. 198 1. Applied regression analysis. John Wiley and Sons, New York 709, 13.

17. Duncan, S., Schapaugh, W., 1997. Relay-intercropped soybean in different water regimes, planting patterns, and winter wheat cultivars. Journal of production agriculture 10, 123-129.

18. Egli, D.B., Bruening, W.P., 2000. Potential of early-maturing soybean cultivars in late plantings. Agronomy Journal 92, 532-537.

19. Fehr, W.R., Caviness, C.E., 1977. Stages of soybean development.

20. Fischer, R.A., 1976. Density and row spacing effects on irrigated short wheats at low latitude. The Journal of Agricultural Science 87, 137-147.

21. Fischer, R.A., 1985. Number of grains in wheat crops and the influence of solar radiation and temperature. The Journal of Agricultural Science 105, 447-461.

22. Gallagher, J., Biscoe, P., 1978. Radiation absorption, growth and yield of cereals. The Journal of Agricultural Science 91, 47-60.

23. Greenwood, E., 1976. Nitrogen stress in plants. Advances in Agronomy. Elsevier, pp. 1-35.

24. Jeffers, D.L., Triplett, G.B., 1979. Management needed for relay intercropping soybeans and wheat. Ohio Report on Research and Development in Agriculture, Home Economics and Natural Resources 64, 67-70.

25. Kantolic, A.G., Slafer, G.A., 2001. Photoperiod sensitivity after flowering and seed number determination in indeterminate soybean cultivars. Field Crops Research 72, 109-118.

26. Kiniry, J., Jones, C., O'toole, J., Blanchet, R., Cabelguenne, M., Spanel, D., 1989. Radiation-use efficiency in biomass accumulation prior to grain-filling for five grain-crop species. Field Crops Research 20, 51-64.

27. Lázaro, L., Abbate, P.E., 1997. Rendimiento potencial en trigo en siembras con surcos espaciados. Rev. Fac. de Agronomia UBA 17, 81-83.

28. Leonard, E., 1962. Inter-relations of vegetative and reproductive growth, with special reference to indeterminate plants. The Botanical Review 28, 353-410.

29. Monteith, J., Moss, C., 1977. Climate and the Efficiency of Crop Production in Britain [and Discussion], Philos. T. Roy. Soc. B, 281, 277-294.

30. Monzon, J.P., Sadras, V.O., Abbate, P., Caviglia, O.P., 2007. Modelling management strategies for wheatsoybean double crops in the south-eastern Pampas. Field Crops Research 101, 44-52.

31. Porter, P.M., Khalilian, A., 1995. Wheat response to row spacing in relay intercropping systems. Agronomy Journal 87, 999-1003. 
32. Puckridge, D., Donald, C., 1967. Competition among wheat plants sown at a wide range of densities. Australian Journal of Agricultural Research 18, 193-211.

33. Reinbott, T.M., Helsel, Z., Helsel, D., Gebhardt, M., Minor, H., 1987. Intercropping Soybean into Standing Green Wheat 1. Agronomy Journal 79, 886-891.

34. Senigagliesi, C., 1998. Intersiembra de soja en cultivo de trigo. Manejo del Suelo and Labranzas No 1. EEA INTA Pergamino 1.

35. Shibles, R., Weber, C., 1966. Interception of Solar Radiation and dry matter production by various soybean planting Patterns1. Crop Science 6, 55-59.

36. Tompkins, D., Fowler, D., Wright, A., 1991. Water use by no-till winter wheat influence of seed rate and row spacing. Agronomy Journal 83, 766-769.

37. Urosa, R., Ascencio, J., 1993. Arquitectura y caracterización fisiológica de la cobertura de plantas de soja Glycine max (L). Merr. var Júpiter en condiciones de campo. Agron. Trop 43, 145-172.

38. Wallace, S., Bacanamwo, M., Palmer, J., Hull, S., 1996. Yield and yield components of relay-intercropped wheat and soybean. Field Crops Research 46, 161-168.

39. Wallace, S., Whitwell, T., Palmer, J., Hood, C., Hull, S., 1992. Growth of relay intercropped soybean. Agronomy Journal 84, 968-973.

40. Zadoks, J.C., Chang, T.T., Konzak, C.F., 1974. A decimal code for the growth stages of cereals. Weed research 14, 415-421. 